\title{
Cartt v. Superior Court: Notice and Consumer Class Actions in California
}

In Cartt v. Superior Court, ${ }^{1}$ the court permitted a consumer class action to proceed under state law without individual notice to class members even though those not notified might not be bound by res judicata. The court viewed the Supreme Court's decision in Eisen $v$. Carlisle \& Jacquelin ${ }^{2}$ as interpreting the language of Federal Rule of Civil Procedure $23^{3}$ and thus as mapplicable to consumer class actions in California. Under this analysis the court suggested that trial courts should focus on the adequacy of representation in consumer class actions and that they need not require individual notice to absent class members in all cases. The court further reasoned that even if Eisen were read as holding that due process requires individual notice to bind absent parties, such a holding relates only to the question of the notice required to preclude absent plaintiffs from relitigating the issues and not to the separate issue of what type of notice is necessary to maintain a class action in the first place. This concept of two distinct purposes of notice in class actions is found neither in the Eisen decision nor in California class action precedent. To determine the appropriate form of notice for maintaining a class action, the court developed a balancing test which weighs the need to protect a defendant from future lawsuits against the economic feasibility of requiring a plaintiff to give adequate notice to all class members. Under this test, where notice is costly compared to the small individual losses of class members, the usual case in consumer class actions, the court determined that expensive individual notice is unnecessary because of the improbability that future plaintiffs will bring actions to recover small anounts.

The facts of Cartt and its procedural posture are set forth in Part I of this note. Part II outlimes the importance of the class action as a remedy for consumers with small individual claims. Part III examines the manner in which the court in Carit dealt with Eisen, the protection available to class action defendants, and the function served by notice when absent class members are not bound by the judgment entered in a class action.

1. 50 Cal. App. 3d 960, 124 Cal. Rptr. 376 (2d Dist. 1975) (Kaus, P.J.) (Ashby \& Loring, JJ., concurring), hearing denied, 52 Cal. App. 3d 48 (subsequent bistory table) (1975).

2. 417 U.S. 156 (1974).

3. 28 U.S.C. Rule 23 (1970). 


\section{Facts and Procedural Posture of the Case}

In 1970, Sandra Cartt filed a class action ${ }^{4}$ on behalf of herself and all Standard Oil of California credit card purchasers of Chevron F-310 gasoline in Southern California. ${ }^{5}$ She alleged that since January 1970, Standard had widely advertised that its gasoline would significantly reduce exhaust emissions, thereby reducing air pollution. Cartt claimed that these representations were false, that Chevron F-310 did not reduce emissions, or worse, that it "was positively harmful to automobiles and the environment." Plaintiff alleged that she and the class she sought to represent had relied on these advertisements and purchased at least 300 million gallons of F-310 gasoline at an estimated five cents per gallon above the prevailing market price for gasoline in Southern California. The complaint prayed for $\$ 15,000,000$ in actual damages and $\$ 15,000,000$ in punitive damages to be awarded to the American Cancer Society or other organizations concerned with health, or to the plaintiffs, as the court deemed proper. ${ }^{7}$

Plaintiff delayed trial to await the results of a Federal Trade Commission proceeding charging Standard with deceptive advertising of Chevron F-310 gasoline. Finally, in November 1974, the Federal Trade Commission issued a cease and desist order against Standard, finding that the advertisements were false, misleading, and deceptive in violation of section 5 of the Federal Trade Commission Act. ${ }^{8}$

In January 1975, the trial court certified a class consisting of those Southern California residents who at any time between January 20 , and April 20, 1970, were named Standard credit card holders, who had read or heard the F-310 advertisements, and who had purchased by credit card any quantity of F-310 in reliance on those advertisements.

In February 1975, the trial court ordered the plaintiff to send notice of the action, by first or third class mail, to all 700,000 current Standard credit card holders residing in Southern California. The

4. Sandra Cartt brought her case under Car. Code Crv. Pro. \$ 382 (West 1973): [W] hen the question is one of a common or general interest, of many persons, or when the parties are numerous, and it is impracticable to bring them all before the court, one or more may sue or defend for the benefit of all.

5. Plaintiff's chances of maintaining this suit as a consumer class action did not at first look promising. Both state and federal courts had previously rejected as unmanageable class actions brought by consumers to recover illegal overcharges on gasoline. See Philadelphia v. American Oil Co., 53 F.R.D. 45 (D.N.J. 1971); Devidian v. Automotive Serv. Dealers Ass'n., 35 Cal. App. 3d 978, 111 Cal. Rptr. 228 (5th Dist. 1973).

6. 50 Cal. App. $3 d$ at 963,124 Cal. Rptr. at 378.

7. Id. The defendant estimated that each class member's actual damage would probably vary between 50 cents and $\$ 5.00$. Id. at 963 n.2, 124 Cal. Rptr. at 378 n.2.

8. Id. at 964,124 Cal. Rptr. at 378 . This order is being appealed by Standard. Id. 
apparent reason for requiring the plaintiff: to notify 1975 credit card holders was that Standard had not retained a list of credit card holders for the relevant months of 1970 . Even if a list of 1970 holders had existed, it would have contained only "candidates for membership" im the class. To determine whether such a candidate had purchased F-310 during the relevant period, Standard would be forced to search its microfilm records of 1970 purchases, a procedure which would require an estimated one hour per card holder. ${ }^{9}$

The cost of the individual notice ordered by the trial court was estimated at $\$ 68,718$, a hefty expense for plaintiff Cartt who earned less than $\$ 15,000$ a year, especially when the notice would reach only "candidates for class membership."10

On appeal, the California District Court of Appeal found that:

Neither due process nor the integrity of the class action process demands such useless and wasteful procedures! ${ }^{11}$

The case was remanded to the trial court to consider requiring notice by publication that would be meaningful (that would have a reasonable chance of reaching a substantial percentage of the class members). ${ }^{12}$

\section{II}

\section{The Consumer Class Action}

The consumer class action has been termed "the judicial analogue

9. Id. at 964-65, 124 Cal. Rptr. at 379. This estimate was provided by Standard, based on an experiment made to determine the identity of possible F-310 purchasers in the company's Western Operations region. The total cost of that search was estimated at $\$ 9,426,558$. Id. at 965 n.7, 124 Cal. Rptr. at 379 n.7. This cost estimate covered several states while the plaintiff would need to determine credit card holders in only eight counties of one state; and, of course, Standard may have sought to inflate the figure to frighten the court.

Although the trial court required individual notice to current credit card holders, it determined that due process did not require the plaintiff to search Standard's microfilm records to identify and notify actual class members.

10. Id. at 965, 124 Cal. Rptr. 379-80.

11. Id. at 967, 124 Cal. Rptr. at 381 .

12. Id. at 974, 124 Cal. Rptr. at 386. This part of the court of appeal's opinion was quoted with approval by the California Supreme Court in a rccent case refusing to dismiss a class action on the grounds of forum non conveniens. See Archibald v. Cinerama Hotels, 15 Cal. 3d 853, 861, 544 P.2d 947, 953, 126 Cal. Rptr. 811, 817 (1976).

On remand, the trial court ordered that notice be published one time in 36 newspapers in the eight Southern California counties where the class members resided, anticipating that such notice would reach 50 percent of the potential class members. Standard is presently appealing the denial of a motion to dismiss and also is contending that a one-time newspaper publication violates the court of appeal's instructions that meaningful notice be given. Standard contends that notice should be published at least four times and reach more than $\mathbf{5 0}$ percent of potential class members. Standard Oil Co. v. Superior Ct. (Cartt, Real Party in Interest), Civil No. 48270 (L.A. County Super. Ct., March 18, 1976). 
to the mass demonstrations of the streets."13 The aggregation of claims in a class action permits economies of scale in litigation, saves judicial resources, and diminishes administrative paper work. Such aggregation provides an effective remedy for the consumer who along with many others has been economically harmed, but whose anticipated recovery is too small to cover the expense of litigating, and who thus may have little imcentive to sue. ${ }^{14}$ If the class prevails, the expense of litigation is spread among all who benefit. Since wimdfall profits can be recovered from wrongdoers who would otherwise be immune from prosecution because of the economic barrier to bringing individual lawsuits, ${ }^{10}$ consumer class actions may deter deceptive busimess practices and thus benefit society as a whole by decreasing the imcidence of fraudulent practices. ${ }^{16}$

Critics have attacked consumer class actions, argumg that they may mcrease litigation by enabling some consumers to sue who would not sue were there no class remedy. ${ }^{17}$ Critics also claim that the legitimate purposes of class actions are easily abused. Simce attorney's fees often are awarded, a recovery of trivial claims for a large class can produce substantial attorney's fees; this encourages strike suits that benefit only the attorney. ${ }^{18}$ Further, the social costs of consumer class actionsexcessive litigation of small claims, loss of the benefits of earlier advertising, and increased consumer prices-may outweigh the potential benefits, thus creating illusory remedies that can actually liarm the consumer who chooses to litigate rather than accept the defendant's unlawful conduct. ${ }^{10}$

Yet almost all commentators have recognized the need to protect injured consumers. ${ }^{20}$ Proposals for better consumer protection lave

13. Starrs, The Consumer Class Action-Part II: Considerations of Procedure, 49 B.U.L. REv. 407, 408 (1969).

14. The typical consumer class action has one or both of two significant characteristics. First, the class is large, usually more than several hundred members. Second, individual damages are small, usually less than a few hundred dollars. See Landers, Of Legalized Blackmail and Legalized Theft: Consumer Class Actions and the SubstanceProcedure Dilemma, 47 S. CAI. L. REv. 842, 844 (1974).

15. Starrs, supra note 13 , at 408 .

16. "When the cost of engaging in prohibited conduct outweighs the benefits of that conduct, the conduct will cease or be substantially altered." Eovaldi, Private Consumer Substantive and Procedural Remedies Under State Law, 15 ANTTTRUST BuLL. 255, 275-76 (1970).

17. See Landers, supra note 14 , at 847.

18. See Comment, Consumers, Class Actions, and Costs: An Economic Perspective on Deceptive Advertising, 18 U.C.L.A.L. REv. 592, 604 (1971).

19. See Rice, Remedies, Enforcement Procedures and the Duality of Consumer Transaction Problems, 48 B.U.L. REv. 559 (1968).

20. See, e.g., Smit, Are Class Actions for Consumer Fraud a Fraud On the Consumer, 26 Bus. LAw. 1053 (1971); Comment, Mass Compensatory Relief: The Inade- 
included new consumer education programs, ${ }^{21}$ better state policing programs, ${ }^{22}$ and a nore effective administrative remedy. ${ }^{23}$ However, consumer class actions lave provided the inost effective protection because of the adverse publicity they generate, and because of the compensation they often provide for victims of fraudulent business practices.

In California, both the courts and the legislature are committed to the use of class actions in cases involving consumers. ${ }^{24}$ The courts have allowed consumers to bring class actions to recover for illegal overcharges on taxi fares ${ }^{25}$ and freezers. ${ }^{26}$ Class actions liave also been held proper on behalf of owners of notes in default secured by deeds of trust, ${ }^{27}$ and on behalf of purcliasers of trucks to require the inanufacturer to recall and replace defective wheels. ${ }^{28}$ Moreover, the California legislature has improved the class action remedy available to consumers by enacting the Consumers' Legal Remedies Act ${ }^{29}$ which offers procedural advantages ${ }^{30}$ over section 382 of the California Code of Civil Procedure. ${ }^{31}$ Because the statute was not intended to be an exclusive

quacy of the Class Action \& the Need for Procedural Alternatives, 24 Sxracuse L. Rev. 1341 (1973); Comment, Consumers, Class Actions, and Costs: An Economic Perspective on Deceptive Advertising, 18 U.C.L.A.L. REv. 592 (1971).

21. Comment, Consumers, Class Actions, and Costs: An Economic Perspective on Deceptive Advertising, supra note 20, at 607-14.

22. Smit, supra note 20 , at 1078.

23. Comment, Mass Compensatory Relief: The Inadequacy of the Class Action \& the Need for Procedural Alternatives, supra note 20, at 1363-65.

24. Numerous court cases have widened the effectiveness of consumer class actions. Previte v. Lincolnwood, Inc., 48 Cal. App. 3d 796, 122 Cal. Rptr. 194 (1st Dist. 1975) (no affirmative response is required for absent plaintiffs to remain in a class after receiving notice); Southern Cal. Edison Co. v. Superior Ct., 7 Cal. 3d 832, 500 P.2d 621, 103 Cal. Rptr. 709 (1972) (defendants cannot compel, except by subpoena, depositions of unnamed class members with the intention of excluding all class members who do not respond); La Sala v. American Sav. \& Loan Ass'n., 5 Cal. 3d 864, 489 P.2d 1113, 97 Cal. Rptr. 849 (1971) (the court may not dismiss a class action that has been settled on terms favorable to the named plamtiff, but not to the class as a whole, without notice to the class).

25. Daar v. Yellow Cab Co., 67 Cal. 2d 695, 433 P.2d 732, 63 Cal. Rptr. 724 (1971).

26. Vasquez v. Superior Ct., 4 Cal. 3d 800, 484 P.2d 964, 94 Cal. Rptr. 796

27. Chance v. Superior Ct., 58 Cal. 2d 275, 273 P.2d 849, 23 Cal. Rptr. 761 (1962).

28. Anthony v. General Motors Corp., 33 Cal. App. 3d 699, 109 Cal. Rptr. 254 (2d Dist. 1973). Class actions have also been allowed on behalf of welfare recipients against county and state agencies. Adkins v. Leach, 17 Cal. App. 3d 771, 95 Cal. Rptr. 61 (1st Dist. 1971); Hyplite v. Carleson, 52 Cal. App. 3d 566, 125 Cal. Rptr. 221 (1st Dist. 1975).

29. Cal. Crv. Code $\S \S 1750-84$ (West 1973).

30. The act anthorizes the court to decide which party should pay the cost of notice, and to order notice by publication if it finds that personal notice is unreasonably expensive or if it appears that all members of the class cannot bo notified personally. Id. $\& 1781(\mathrm{~d})$.

31. See note 4 supra. 
remedy, ${ }^{32}$ the class action plaintiff may proceed as Cartt did under section 382 or under the Consumers' Legal Remedies Act, ${ }^{33}$ a remedy unavailable to Cartt when she filed her law suit. ${ }^{34}$

\section{III}

\section{Notice Requtrements in Class ACtions}

\section{A. Confronting Eisen}

The court of appeal in Cartt was faced with a dilemma. If it required individual notice to be sent to all ascertainable class members, the expense involved would curtail the litigation. ${ }^{35}$ If, on the other hand, it allowed the action to proceed with soinething less than individual notice, it would have to confront the United States Supreme Court's decision in Eisen v. Carlisle \& Jacquelin, ${ }^{36}$ which required class

32. Cal. Crv. Code $\$ 1752$ (West 1973) provides:

The provisions of this title are not exclusive. The remedies provided herein for violation of any section of this title or for conduct proscribed by any section of this title shall be in addition to any other procedures or remedies for any violation or conduct provided for in any other law.

33. Many consumers may choose not to sue under the Consumers' Legal Remedies Act because it also contains procedural disadvantages. Under the Act, 30 days prior to the commencement of an action for damages the consumer is required to notify the manufacturer in writing and demand that he correct, repair, replace, or otherwise rectify the alleged defective merchandise. CaL. CTv. CODE $\$ 1782$ (a) (1) \& (2) (West 1973). However, a dennand is unnecessary if the action is for injunctive relief. Id. $\$ 1782$ (d). Additionally, no damages may be awarded if the alleged violation is unintentional and the defendant has made appropriate correction, replacement, or repair of the merchandise. $I d . \S 1874$.

34. A Uniform Class Action Act has been proposed by the National Conference of Commissioners on Uniform State Law. The Act adopts an approach similar to that taken in Cartt. See text accompanying notes $42-43$ infra. It gives the trial court discretion to prescribe the type of notice to be used, directing the court to consider the interests of the class, the relief requested, the cost of notifying members, and the possible prejudice to class members who do not receive notice. UNIFORM CLASS ACTION ACT \$ 8(c) (Tent. Draft No. 4, 1976) (on file at California Law Review). The Act also provides that personal notice must be given if the whereabouts of a class inember with a claim over $\$ 100$ can be ascertamed with reasonable diligence. Id. \$ 8(d). For absent plaintiffs with claims under $\$ 100$ the Act would give the court absolute discretion to determine the kind of notice necessary, and it expresses approval of notice distributed through newspapers, radio, or television. However, notice cannot be dispensed with entirely; the court must, at a minimum, "assure effective distribution of information . . . to apprise the members of the class of the pendency of the action." Id. $\$ 8(f)$. The court may also use discretion in assessing the cost of notice to promote the interests of justice. For example, the Act provides that if a counterclaim is asserted against a plaintiff class, the expense of notice shall be divided equally between the plaintiff and the defendant. $I d . \$ 8(\mathrm{~g})$.

35. Cartt v. Superior Ct., 50 Cal. App. 3d 960, 966, 124 Cal. Rptr. 376, 380 (2d Dist. 1975).

36. 417 U.S. 156 (1974). 
action plaintiffs to send individual notice to all ascertainable class members.

The court could have dealt with Eisen in any of three relatively straightforward ways. It could have held simply that Eisen was based solely on the requirements of Federal Rule of Civil Procedure 23, ${ }^{37}$ which does not bind California courts, thus leaving the state free to determine its own notice requirements in class actions proceeding under state law. Alternatively, the court could have found that Eisen was constitutionally based and that due process requires individual notice to all class members identifiable through reasonable effort. The court might then have found unreasonable the effort required to ascertain the identity of individual class members in Cartt, permitting it to conclude that imdividual notice was unnecessary. However, the procedure required to identify class mennbers in Eisen was just as burdensome, expensive, and comphicated as that required in Cartt. ${ }^{38}$ Thus, the Cartt court would have found it difficult to distinguish the result in Eisen on the level of effort required to identify and notify class members; under this analysis, mdividual notice would have been required in Cartt.

Finally, the court could have read Eisen as holding that due process requires imdividual notice to ascertainable class meinbers under all circumstances. If the court had read Eisen in this way, the action in Cartt could not have proceeded unless the plaintiff financed individual notice to all class nembers. ${ }^{39}$

\section{B. The Cartt Rationale}

In Cartt, the court dealt with Eisen in a more complicated way. It held first that Eisen was not constitutionally based, but simply interpreted Federal Rule of Civil Procedure $23,{ }^{40}$ and so was not binding on California courts. ${ }^{41}$ This left the court free to deternine the form of notice required in California class actions. In making this determination, the court focused upon the adequacy of class representation

37. 28 U.S.C. Rule 23 (1970).

38. In Eisen, the plaintiffs were odd lot traders on the New York Stock Exchange who alleged that some brokerage firms had monopolized odd lot trading, setting the odd lot differential at an excessive level in violation of the Sherman Act. To ascertain the naines of class members, the plaintiff would have had to compare computerized teletypes that transinitted odd lot transactions to Carlisle \& Jacquelin from general service brokers with the computerized records of the general service brokers. 417 U.S. at 166 n.5.

39. If Eisen were read as resting on due process considerations rather than on the language of Federal Rule of Civil Procedure 23, it is unlikely that the notice provisions of the Consumers' Legal Remedies Act, CAL. Crv. Code $\$ \S 1750-84$ (West 1973), or of the Uniforin Class Action Act could survive constitutional serutiny. See notes 29 and 34 supra.

40. 28 U.S.C. Rule 23 (1970).

41. 50 Cal. App. 3d at 967-68, 124 Cal. Rptr. at 381. 
by the named plaintiff. Although individual notice may occasionally be required to ensure adequate representation, it is not mandated in all class actions. The court reasoned that if the named plaintiff is a true and competent adversary of the defendant, all common questions of law and fact will be litigated, and absent plaintiffs will effectually have had their day in court under conditions meeting due process standards. This part of the Cartt opinion emphasized that the purpose of notice in a class action is to ensure that class nembers who do not participate in the litigation are adequately represented, and that the adequacy of representation must be judged in light of the circumstances of each particular case.

The court did not stop, however, with this determination that Eisen was a non-constitutional decision. It went on to lold that even if Eisen had been based on due process considerations, the notice mandated by Eisen was that required to ensure the res judicata effect of a class adjudication, not that required to maintain the class action itself. $^{42}$ It is this distinction that gives Cartt its novelty and significance, and also points out its limitations.

The court determined that different standards for judging the adequacy of notice should be applied to these two separate functions served by the notice requirement. Eisen might require individual notice to bimd absent class meinbers through res judicata, but something less than individual notice would suffice to allow a class action to proceed in court. ${ }^{43}$

42. Id. at 968, $124 \mathrm{Cal}$. Rptr. at 381-82.

43. In Home Sav. \& Loan Ass'n v. Superior Ct., 42 Cal. App. 3d 1006, 117 Cal. Rptr. 485 (2d Dist. 1974), the court characterized one-way interventiou by plaintiffs as a "classic no wim option" for the defendant. The court explamed:

Under the doctrine of collateral estoppel a defendant who litigates and loses issues tendered in a class action filed by an individual member of the class may be estopped in subsequent hitigation with other members of the class to deny the validity and binding effect of the judgment against him in the first action. Contrariwise, if defendant prevails in the first cause of action involving merely individual members of the class, no other members of the class need be bound by the outcome.

42 Cal. App. 3d at 1011, 117 Cal. Rptr. at 488.

If a defendant wins a class action suit he can assert collateral estoppel against an absent plaintiff who seeks to attack the judgment. But if the court accepts a claim by the absent plaintiff that notice was insufficient, the defendant would lose the res judicata protection that class actions characteristically provide. However, if the class action plaintiff wins, the defendant might convince the court that the notice provided was inadequate, and therefore that the principles of mutuality of estoppel should forbid absent plaintiffs from taking advantage of a victory when they would not have been bound by defeat. See Note, Managing the Large Class Action: Eisen v. Carlisle \& Jacquelin, 87 HARv. L. Rev. 426, 438 n.91 (1973). But see Note, Expanding the Impact of State Class Action Adjudications to Provide an Effective Forum for Consumers, 18 U.C.L.A. L. REv. 1002, 1027 (1971), where the author argues that eliminating mutuality in most consumer class actions would not lead to unfair results because the very fact that a con- 
The type of notice required would depend on where a case fell in the spectrum of class action cases, ranging from those with relatively few members whose claims were relatively large to those with innumerable members whose claims were insignificant. At the first end of the spectrum, class members would be nost likely to bring their claims as individuals if no class suit commenced, and notice would be relatively inexpensive in relation to the expected recovery; at the other end, no individual suit was likely while notice would be expensive. The court placed the Cartt suit at the latter end of the spectrun and formulated a balancing test which would allow class actions to proceed without individual notice

Where the economic realities involved in giving "adequate" notice, coinpared to the small individual losses of class members, would effectively negate any class action. ${ }^{44}$

This test, by focusing only on the size of the individual claims in relation to the cost of individual notice, omits express consideration of the defendant's interest in a final adjudication of liability. Since the court has acknowledged that absent members will not be bound by the class judgment, the decision invites subsequent suits by absent members.

\section{The Defendant's Interests}

Despite the court's apparent lack of concern for the defendant's interests, its pragmatic approach to the notice problem in class actions may protect the defendant in practice if not in theory. The harm that a defendant might suffer can be evaluated only by examining the likeli-

sumer brought a class action against the defendant should have been sufficient to alert the defendant to litigate the matter fully. This approach was followed in Anthony v. General Motors Corp., 33 Cal. App. 3d 699, 109 Cal. Rptr. 254 (2d Dist. 1973), where a class action was allowed to proceed even though some class members were not California residents and thus not subject to the jurisdiction of the California courts unless they voluntarily consented to jurisdiction. Hence, an adverse judgment could not bind them outside California. The court held that the trial judge had the power to define the class by determining notice, damage, and jurisdiction. Thus the defendant's objection to including out-of-state class members was not grounds for dismissal.

44. 50 Cal. App. 3d at 971, $124 \mathrm{Cal}$. Rptr. at 384. Federal cases do not agree with Carti's balancing test or its recognition, in determining the form of notice, of the advantages gained by allowing a class action to proceed. Since Eisen, Federal Rule of Civil Procedure 23(c)(2) has been read to mandate that once a class member can be identified through "reasonable effort," individual notice must be given. In re Hotel Telephone Charges, 500 F.2d 86, 91 (9th Cir. 1974) (class action brought on behalf of forty million plaintiffs to recover an illegal $2 \%$ surcharge on telephone use). Even though the cost of notice would have exceeded the average recovery, the court held that individual notice had to be given since the naines and addresses of class members were available in defendant's records. See also Buford v. American Fin., 333 F. Supp. 1243 (N.D. Ga. 1971). 
hood of subsequent suits rather than analyzing in the abstract the res judicata effect of proceeding with less than individual notice.

If the original class action plaintiff wins a nonetary award for the class, absent nembers are likely to assert theinselves not by bringing a subsequent suit, but by claiming their share of the award. In this situation, the defendant would not be threatened by subsequent litigation on the same issue. If instead, the initial plaintiff loses, Cartt would not prohibit absent nneınbers froin relitigating the same claim. Nevertheless, these new plaintiffs would have to confront the stare decisis effect of the first decision, an obstacle which the court recognized. ${ }^{45}$ The odds of victory would seem so slim in these circunstances that few, if any, plaintiffs or their lawyers would undertake the expense of new litigation. Further, the new plaintiffs would liave to address the issue of res judicata, certain to be raised by the defendant. The possibility of losing on this issue would add to the risks of litigation. In addition, the number of neinbers in the second class action would be fewer than the number in the original suit since those bound by the original suit could not participate in the second one. Thus, the sum of the claims would be sinaller and the economic incentives in bringing the suit would be that inuch less. The Cartt court recognized the improbability of renewed litigation:

[U]nder all of the circumstances that may prevail in the future-the improbability that anyone else who is only minimally darnaged will undertake and underwrite new hitigation, the statute of limitations, the doctrine of res judicata and, above all, the impact of stare decisis -renewed harassment is nothing but a remate theoretical possibility. ${ }^{40}$

Only when the stare decisis effect of a previous decision favors a subsequent plaintiff are the practical deterrents to renewed litigation removed. If the first plaintiff has requested a remedy which does not include individual dainages, such as an injunction, lower prices, or a public apology, a subsequent plaintiff may seek damages for the class, building his case on the stare decisis effect of the first action. The probability of this occurring is low, however, because if the recovery of damages was at all possible, the first plaintiff undoubtedly would have sought damages, if only to pay for litigation expenses. Alternatively, if a second plamtiff also wants a form of rehef that does not include daunages, renewed litigation is even more unlikely. The nature of non-

45. 50 Cal. App. 3d at 969, 124 Cal. Rptr. at 382. The doctrine of stare decisis would be particularly powerful since absent class members would probably assert claims identical to those asserted by the representative plaintiff. Dam, Class Action Notice: Who Needs It?, 1974 Sup. Cr. Rev. 97.

46. 50 Cal. App. 3d at 969, 124 Cal. Rptr. at 382. 
monetary relief provides little incentive for a new claim; moreover, a court would not order the same defendant again to lower prices, donate to a public interest group, or provide whatever compensation is requested.

Although the court did not expressly analyze the degree of prejudice to a defendant exposed to the possibility of litigating the same issue more than once, the likelihood of renewed litigation may be very remote. Where the possibility exists, the court suggested that defendants may bind all class members by providing individual notice of pending litigation at their own expense. ${ }^{47}$

\section{The Purpose of Notice}

The court of appeal did not dispense with notice altogether in permitting Cartt's class action to proceed, ${ }^{48}$ despite its suggestion that absent class members did not lave to be legally bound because of the small likelihood of subsequent litigation. Instead, it instructed the trial court to define a form of effective notice by publication. ${ }^{48}$ This imstruction raises the question of the purpose and effect of ordering such notice.

If this notice will not bind members of the class, then it accomplishes little more than publicizing the suit and strongly censuring the defendant for conduct which has harmed many consumers. Yet, such public censorship seems imappropriate beforc a judgment is entered against the defendant. Another purpose of the notice could be to

47. However, the Supreme Court in Eisen suggested that shifting the cost of notice to the defendant might involve constitutional problenns. Eisen v. Carlisle \& Jacquelin, 417 U.S. 156, 178-79 (1974). Even if a court requires that a defendant only advance the cost, it is unlikely that a successful defendant will recover this anount. Thus the defendant may be deprived of property (the cost of notice) in a procedure which was not a full and fair hearing on the merits. McCall, Due Process and Consumer Protection: Concepts and Realities in Procedure and Substance-Class Action Issues, 25 HAST. LJ. 1351, 1399 (1974). Cartt acknowledged this possibility of due process problems but avoided the issue by stating:

As far as shifting all or part of the cost burden of giving notice to the defendant

is concerned, probably the less we say about this problem, at this time, the better.

50 Cal. App. 3d at 974, 124 Cal. Rptr. at 386.

Some courts have indicated that since the defendant benefits from notice, he should bear its cost. Dolgow v. Anderson, 43 F.R.D. 472, 499 (E.D.N.Y. 1968); Berland v. Mack, 48 F.R.D. 121, 133 (S.D.N.Y. 1969) (the cost of notice should be borne by the party who requests it). This was also suggested in Cartt when the court reminded the defendant that there was nothing to prevent it from "stuffing" notice into regular credit card correspondence, at its own expense, if it wanted credit card holders to receive individual notice. $50 \mathrm{Cal}$. App. 3d at 974, $124 \mathrm{Cal}$. Rptr. at 386.

48. In Massey v. Bank of America, 56 Cal. App. 3d 29, 33 n.2, 128 Cal. Rptr. 144, 147 n.2 (1st Dist. 1976), the court noted: "Cartl in fact concerns only the form of notice to be given, and does not purport to negate the need for some notice."

49. 50 Cal. App. 3d at 974, 124 Cal. Rptr. at 386. 
invite class members to come forward with their claims if the suit ends in their favor. However, the defendant, if unsuccessful, could be required to notify all class inembers for the purpose of distributing the award. Notice that does not bind absentee class nneinbers might also be designed to ensure adequate representation by inviting class nnembers to challenge the class representative or opt out. But class nembers have little incentive to opt out when they will not be bound by remaining in the class. ${ }^{\circ 0}$ At best, then, the prescribed notice will have the salutory effect of informing class nembers that someone is vindicating their rights.

\section{Concluston}

Although the court of appeal developed a practical approach to consumer class actions in Cartt, it failed to resolve the issue of what kind of notice is required to bind absent class nnembers. The main value of the court's bifurcated notice standard is to permit certain types of consumer litigation to go forward in class action form when the defendant's wrongful gains miglit otherwise remain unchallenged. Nevertheless, this bifurcated standard obscures the res judicata effect of any class action litigation. If Eisen was concerned solely with Rule 23 , then in California less than individual notice may bind all class menbers; if Eisen was based on constitutional due process standards, then no class member is bound who did not receive individual notice. The court's ambivalence about the Eisen decision leaves in doubt the binding effect of a class action judgment in California where individual notice is not given.

Despite its analytical shortcomings, the decision reflects judicial notice of the economic difficulties of consumer class actions. The court concentrated on the adequacy of representation to protect the interests of absent plaintiffs and upon the practicalities of litigation to protect the interests of the defendant. The court has provided consumers with a inore accessible reinedy, but at the saine time it has removed from the defendant the protection of individual notice. In doing so, the court has created a pool of "private attorneys general" to redress the

50. Substantial impediments stand in the way of a consumer opting out even where he will be bound by the judgment. First, the right of a class member to opt out of the class and proceed to litigate the issue on his own is no more than a theoretical possibility where an individual's stake is so small as to make a separate action impractical. See Kaplan, Continuing Work of the Civil Committee: 1966 Amendments of the Federal Rules of Civil Procedure (I), 81 HARv. L. REv. 356, 391 (1967); Note, The Importance of Being Adequate: Due Process Requirements in Class Actions Under Federal Rule 23, 123 U. PA. L. REv. 1217 (1975). Second, consumers often fail to comprehend the significance of opting out. See Miller, Problems of Giving Notice in Class Actions, 58 F.R.D. 313, 322 (1973). 
wrongs of the marketplace while generating a common fund of recovery to support an award of attorney's fees. While easing the plaintiff's burden, the result raises the specter of increased litigation of trivial claims whose main beneficiary will be the plaintiff's attorney. ${ }^{51}$ Nevertheless, the decision ensures that for the present consumer class actions will continue to be widely used in California to deter fraudulent consumer practices.

Linda J. López

51. Blue Chip Stamps v. Superior Ct., Civil No. 46758 (2d Dist. 1976), is a case in point. The plaintiffs brought a class action on behalf of all persons who redeemed Blue Chip stamps for merchandise between March 1, 1967, and April 28, 1970, to recover overpayments of sales tax, ranging from 1.2 cents to 6.6 cents per book of stamps redeemed. The excess sales tax collected by Blue Chip had been paid to the state. Thus, the state treasury would be required to reimburse Blue Chip for the amount of any judgment against the company, to the benefit of no one except the plaintiffs' attorneys (who were the husbands of the nained plaintiffs). The plaintiffs are relying on Cartt to establish that no pretrial notice should be required.

* B.A. 1970, Cal. State University, Northridge; third-year student, Boalt Hall School of Law; Managing Editor, California Law Review. 